\title{
Enzyme activities in activated sludge flocs
}

\author{
Guang-Hui Yu • Pin-Jing He $\cdot$ Li-Ming Shao • \\ Duu-Jong Lee
}

Received: 15 June 2007 /Revised: 11 September 2007 / Accepted: 12 September 2007 / Published online: 12 October 2007

(C) Springer-Verlag 2007

\begin{abstract}
This study quantified the activities of enzymes in extracellular polymeric substances (EPS) and in pellets. Seven commonly adopted extraction schemes were utilized to extract from aerobic flocs the contained EPS, which were further categorized into loosely bound (LB) and tightly bound (TB) fractions. Ultrasonication effectively extracted the EPS from sludge flocs. Enzyme assay tests showed that the protease activity was localized mainly on the pellets, $\alpha$ amylase and $\alpha$-glucosidase activities were largely bound with LB-EPS, and few protease, $\alpha$-amylase, or $\alpha$-glucosidase activities were associated with the TB-EPS fraction. There exists no correlation between the biochemical compositions of EPS and the distribution of enzyme activities in the sludge matrix. The $44-65 \%$ of $\alpha$-amylase and $59-100 \%$ of $\alpha$ glucosidase activities noted with the LB-EPS indicate heterogeneous hydrolysis patterns in the sludge flocs with proteins and carbohydrates.
\end{abstract}

Keywords Enzymatic distribution - Enzymes · Extracellular polymeric substances · Extraction process . Infrared spectra $\cdot$ Sludge

G.-H. Yu • P.-J. He $(\bowtie) \cdot$ L.-M. Shao

State Key Laboratory of Pollution Control and Resource Reuse, Key Laboratory of Yangtze River Water Environment, College of Environmental Science and Engineering, Tongji University,

Shanghai 200092, People's Republic of China

e-mail: solidwaste@mail.tongji.edu.cn

D.-J. Lee

Department of Chemical Engineering,

National Taiwan University,

Taipei 10617, Taiwan

\section{Introduction}

Biological processes are predominant in municipal wastewater treatment plants (WWTPs). Proteins, polysaccharides, and lipids are the major organic contaminants in municipal wastewater, which must be hydrolyzed to smaller units by extracellular enzymes (Frølund et al. 1995; Cadoret et al. 2002; Sheng and Yu 2006). Protease, $\alpha$-amylase, and $\alpha$ glucosidase should play essential roles in the biological wastewater treatment processes. In the bulk solution of activated sludge, the amount of extracellular enzymes is negligible, indicating that almost all the extracellular enzymes are immobilized in flocs (Frølund et al. 1996). How the extracellular enzymes distribute in sludge flocs determines the contact probability of enzyme with proteins or polysaccharides, hence affecting the process treatment efficiency (Molina-Munoz et al. 2007).

Extracellular polymeric substances (EPS) and cells form bioaggregates, such as biofilms, sludge flocs, and river snow (Nielsen and Jahn 1999). EPS were analyzed after extraction and separation stages (Frølund et al. 1996; Liu and Fang 2003; Gessesse et al. 2003; Comte et al. 2006; Sheng and Yu 2006). EPS in sludge flocs were proposed to exhibit a dynamic double-layer-like structure, composed of loosely bound EPS (LB-EPS) and tightly bound EPS (TBEPS; Poxon and Darby 1997; Ramesh et al. 2006; Li and Yang 2007). The LB-EPS fraction is considered to easily exchange substances with bulk solution, hence having greater impact to numerous sludge processes such as coagulation and dewatering ( $\mathrm{Li}$ and Yang 2007; Ramesh et al. 2007).

Extracellular enzymes of sludge flocs must incorporate with the EPS-cell matrix (Frølund et al. 1996; Gessesse et al. 2003). However, no existing works present data on how enzymes were distributed among the LB-EPS, TB-EPS, 
Table 1 Characteristics of sludge sediment sample

\begin{tabular}{lllll}
\hline $\begin{array}{l}\text { TS } \\
\left(\mathrm{g}^{-1}\right)\end{array}$ & $\begin{array}{l}\text { VSS } \\
\left(\mathrm{g} \mathrm{l}^{-1}\right)\end{array}$ & $\begin{array}{l}\text { SRF } \\
\left(10^{11} \mathrm{~cm} \mathrm{~g}^{-1}\right)\end{array}$ & $\begin{array}{l}\text { Viscosity } \\
(\mathrm{m} \mathrm{Pa} \mathrm{s})\end{array}$ & $\begin{array}{l}\text { SVI } \\
\left(\mathrm{ml} \mathrm{g}^{-1} \mathrm{SS}\right)\end{array}$ \\
\hline $5.46 \pm 0.94$ & $2.56 \pm 0.36$ & $1.86 \pm 0.51$ & $1.22 \pm 0.02$ & 93.5 \\
\hline
\end{tabular}

and pellet fractions. The objective of this paper is to investigate the distribution of enzymes in the sludge flocs. There presents no standard protocol for EPS extraction. Seven EPS extraction processes adopted by Liu and Fang (2002) were utilized here to extract the different fractions of EPS with incorporated enzyme activities measured.

\section{Materials and methods}

\section{Sludge samples}

Activated sludge samples were collected from the aerated basin of a municipal WWTP in Shanghai, China. The plant treats $75,000 \mathrm{~m}^{3}$ day $^{-1}$ of wastewater $(93 \%$ domestic and $7 \%$ industrial sewage) using anaerobic-anoxic-oxic process. The collected sludge samples were transported to laboratory within $30 \mathrm{~min}$ after sampling.

\section{EPS extraction}

The sludges were settled for $1.5 \mathrm{~h}$ at $4^{\circ} \mathrm{C}$ with supernatant being decanted. The sludge sediments were collected, whose characteristics are listed in Table 1 . The sediments were then centrifuged at $2,000 \times g$ for $15 \mathrm{~min}$, and the supernatant was decanted. The discarded fraction of sludge flocs was taken as slime that contained few enzymes (Frølund et al. 1995; Nielsen and Jahn 1999). The collected bottom sediments were resuspended in $0.05 \% \mathrm{w} / \mathrm{w} \mathrm{NaCl}$ solution to its original volume. The suspensions were centrifuged again at $5,000 \times g$ for 15 min with supernatant and solid phase separately collected. The organic matters in the supernatant were the LB-EPS of the sludge samples. Collected sediments were resuspended again with $0.05 \%$ $\mathrm{NaCl}$ solution to the original volumes for further extraction of TB-EPS.

Figure 1 illustrates the extraction processes for TB-EPS from the sediments after LB-EPS extraction. As a control, the EPS in some samples were centrifuged at $4,000 \times g$ for 20 min without adding any chemicals. The ultrasonicated sludge was treated using ultrasonication at $40 \mathrm{kHz}$ and $120 \mathrm{~W}$ for $2 \mathrm{~min}$. The cation exchange resin (CER, Dowex $50 \times 8$, Fluka 44504) extracted sludge at $4{ }^{\circ} \mathrm{C}$ for $1 \mathrm{~h}$ (600 rpm, $70 \mathrm{~g} \mathrm{~g}^{-1}$ volatile suspended solids; VSS). For the rest of the four extraction processes, the sludge was first extracted using ethylenediaminetetraacetic acid (EDTA; $2 \% w / w$ at $4^{\circ} \mathrm{C}$ for $\left.3 \mathrm{~h}\right)$, formaldehyde $\left(36.5 \% \mathrm{w} / \mathrm{w}\right.$ at $4^{\circ} \mathrm{C}$ for $1 \mathrm{~h}$ ), formaldehyde $+\mathrm{NaOH}\left(1 \mathrm{~mol} \mathrm{l}^{-1}\right.$ at $4^{\circ} \mathrm{C}$ for $3 \mathrm{~h}$ ), or formaldehyde + ultrasonication $(40 \mathrm{kHz}$ and $120 \mathrm{~W}$ for $2 \mathrm{~min}$ ). The extracted solutions were centrifuged at $20,000 \times g$ for $20 \mathrm{~min}$. The organic matters in the supernatant were the TB-EPS, while the residues were the pellets.

The $0.45 \mu \mathrm{m}$ polytetrafluoroethylene membranes (Mosu Scientific Equipment, Shanghai, China) and the dialysis
Fig. 1 Procedures for EPS extraction processes

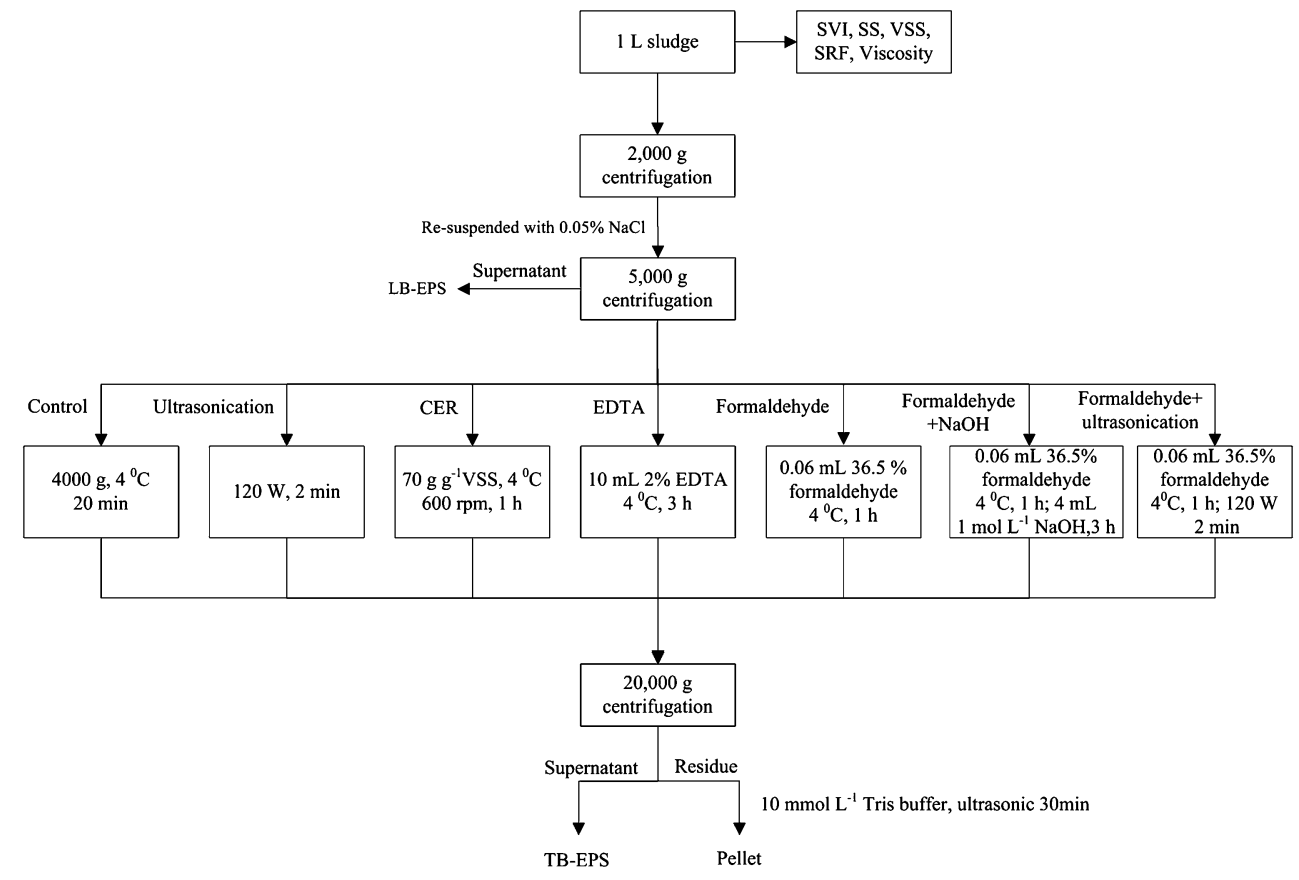


membranes of MWCO of 3,500 Da (Shanghai Sangon Biotechnology, China) removed the particulates and lowmolecular-weight (MW) metabolites in the LB-EPS and TB-EPS solutions. The enzymes in pellets were released by completely disrupting cells using the methods described elsewhere (Gessesse et al. 2003). The pellets of samples were first mixed with $10 \mathrm{mmol}^{-1}$ Tris buffer at $\mathrm{pH} 8$ in ice bath, and then sonicated for a total of $30 \mathrm{~min}$, with $2 \mathrm{~min}$ burst $(120 \mathrm{~W}, 40 \mathrm{kHz})$ followed by 5 -min rest on ice. After $20,000 \times g$ centrifugation for $15 \mathrm{~min}$, the particulates and low-MW metabolites in the supernatant were removed by the two abovementioned membranes.

EPS and sludge characterization

All the analyses were carried out using chemicals of analytical grade. A rotating torque meter (NDJ-7, Shanghai Cany Precision Instrument, China) measured the viscosities of suspensions. The carbohydrate contents in the EPS solutions were measured by the Anthrone method (Gaudy 1962), using glucose as the standard. The contents of proteins and humic substances in the EPS solutions were determined by the modified Lowry method (Frølund et al. 1995), using casein and humic acid (Shanghai Sangon Biotechnology) as the respective standards. The DNA contents in EPS solutions were determined by the diphenylamine colorimetric method (Sun et al. 1999) using fish sperm deoxyribonucleic (DNA; Shanghai Sangon Biotechnology) as the standard. Other sludge parameters, including total solids (TS), VSS, sludge volume index (SVI), and specific resistance to filtration (SRF), were analyzed following the Standard Methods (APHA et al. 1998).

\section{Infrared spectrometry analysis}

The extracted TB-EPS solutions from different processes were lyophilized at $-50^{\circ} \mathrm{C}$ for $48 \mathrm{~h}$. One milligram of freeze-dried TB-EPS extraction solution was mixed with $60 \mathrm{mg}$ of potassium bromide [KBr, infrared (IR) grade]. The IR spectra analysis of freeze-dried TB-EPS samples was then performed on a spectrometer (EQUINOXSS/ HYPERION 2000, Bruker, Germany).

\section{Enzyme assay}

Protease activity was measured using the Lowry method (Lowry et al. 1951) with casein the standard. The $\alpha$ amylase activity was determined by the Bernfeld (1955) method, and glucose was the standard. The $\alpha$-glucosidase activity was measured according to the iodine method (Ministry of Light Industry of China 1993, QB/T 1803$1993)$ with glucose as the standard. Protease and $\alpha$-amylase assays were carried out in triplicate consisting two samples and one blank, while $\alpha$-glucosidase assay was carried out with one sample and one blank.

\section{Results}

Extraction effectiveness of enzymes in the sludge flocs

Tables 2, 3, and 4 list the activities of protease, $\alpha$-amylase, and $\alpha$-glucosidase, respectively, in different fractions of sludge matrix. Restated, the total activities of protease follow: formaldehyde $>$ ultrasonication $=$ formaldehyde + ultrasonication $=$ EDTA $>$ control $>$ CER $=$ formaldehyde + $\mathrm{NaOH}$; those of $\alpha$-amylase follow: ultrasonication $>$ EDTA $>$ formaldehyde $+\mathrm{NaOH}>\mathrm{CER}>$ control $>$ formaldehyde + ultrasonication $>$ formaldehyde; and those of $\alpha$-glucosidase were: ultrasonication $>$ EDTA $>$ control $>$ formaldehyde + $\mathrm{NaOH}>$ formaldehyde $>$ formaldehyde + ultrasonication $>$ CER. The protease activity extracted by formaldehyde+ $\mathrm{NaOH}$ was the lowest among all tests, indicating that a part of protease might be inactivated under the alkaline conditions.

Figure 2 shows the DNA contents in the extracted EPS solutions. The DNA contents in the TB-EPS solutions via formaldehyde, formaldehyde + ultrasonication, and formaldehyde $+\mathrm{NaOH}$ extraction were high $\left(>9 \mathrm{mg} \mathrm{g}^{-1} \mathrm{VSS}\right.$ ), while those via ultrasonication, control, EDTA, and CER

Table 2 Protease activities in sludge flocs

\begin{tabular}{|c|c|c|c|c|}
\hline \multirow[t]{2}{*}{ Extraction processes } & \multicolumn{4}{|c|}{ Protease activities ( $\left.\mu \mathrm{mol} \min ^{-1} \mathrm{~g}^{-1} \mathrm{VSS}\right)$} \\
\hline & LB-EPS & TB-EPS & Pellet & Total \\
\hline Control & & $0.24 \pm 0.03$ & $17.9 \pm 0.68$ & $18.1 \pm 0.48$ \\
\hline Ultrasonication & & $0.38 \pm 0.05$ & $22.8 \pm 3.50$ & $23.2 \pm 2.48$ \\
\hline EDTA & & $0.35 \pm 0.18$ & $12.9 \pm 2.25$ & $13.3 \pm 1.60$ \\
\hline Formaldehyde & 0 & $2.29 \pm 0.83$ & $25.9 \pm 3.12$ & $28.2 \pm 2.28$ \\
\hline Formaldehyde + ultrasonication & & $0.08 \pm 0.08$ & $21.4 \pm 0.91$ & $21.5 \pm 0.65$ \\
\hline Formaldehyde $+\mathrm{NaOH}$ & & $0.38 \pm 0.03$ & $0.68 \pm 0.21$ & $1.06 \pm 0.15$ \\
\hline CER & & $0.06 \pm 0.06$ & $3.01 \pm 0.20$ & $3.07 \pm 0.15$ \\
\hline
\end{tabular}


Table $3 \alpha$-Amylase activities in sludge flocs

\begin{tabular}{|c|c|c|c|c|}
\hline \multirow[t]{2}{*}{ Extraction processes } & \multicolumn{4}{|c|}{$\alpha$-Amylase activities $\left(\mu \mathrm{mol} \min ^{-1} \mathrm{~g}^{-1} \mathrm{VSS}\right)$} \\
\hline & LB-EPS & TB-EPS & Pellet & Total \\
\hline Control & & $2.44 \pm 0.22$ & $2.35 \pm 0.13$ & $11.4 \pm 1.76$ \\
\hline Ultrasonication & & $2.82 \pm 0.01$ & $5.49 \pm 0.79$ & $14.9 \pm 1.81$ \\
\hline EDTA & & $3.29 \pm 0.20$ & $4.50 \pm 0.54$ & $14.4 \pm 1.78$ \\
\hline Formaldehyde & $6.61 \pm 3.03$ & $1.79 \pm 0.03$ & $1.77 \pm 0.0$ & $10.2 \pm 1.75$ \\
\hline Formaldehyde + ultrasonication & & $2.11 \pm 0.17$ & $1.94 \pm 0.09$ & $10.7 \pm 1.75$ \\
\hline Formaldehyde $+\mathrm{NaOH}$ & & $3.67 \pm 0.47$ & $2.01 \pm 0.0$ & $12.3 \pm 1.77$ \\
\hline CER & & $2.95 \pm 0.61$ & $1.96 \pm 0.0$ & $11.5 \pm 1.78$ \\
\hline
\end{tabular}

were generally lower than $1.5 \mathrm{mg} \mathrm{g}^{-1}$ VSS. Hence, the first three extraction schemes contaminated the extracellular materials with intercellular substances (Zhang et al. 1999; Liu and Fang 2003), and were disregarded in the following analyses.

Figure 3 shows the IR spectra of the TB-EPS extracted by different extraction schemes. Peaks at near $3,400 \mathrm{~cm}^{-1}$ $(\mathrm{OH}), 1,640 \mathrm{~cm}^{-1}(\mathrm{CO}, \mathrm{CN}), 1,544 \mathrm{~cm}^{-1}(\mathrm{CN}, \mathrm{NH})$, $1,110 \mathrm{~cm}^{-1}(\mathrm{OH})$, and $1,047 \mathrm{~cm}^{-1}(\mathrm{OH})$ indicate the presence of proteins $\left(1,640 \mathrm{~cm}^{-1}, 1,544 \mathrm{~cm}^{-1}\right)$ and polysaccharides $\left(3,400 \mathrm{~cm}^{-1}, 1,110 \mathrm{~cm}^{-1}\right.$, and $\left.1,047 \mathrm{~cm}^{-1}\right)$, respectively (Kim and Jang 2006; Comte et al. 2006). Hence, proteins and polysaccharides predominant in the TB-EPS samples, correlating with the compositional analysis presented in Table 5. The IR spectra of TB-EPS of control, CER, ultrasonication, formaldehyde, and formaldehyde + ultrasound samples revealed similar absorption bands. In contrast, several significant shifts of absorption bands $\left(1,640 \mathrm{~cm}^{-1}, 1,110 \mathrm{~cm}^{-1}, 1,047 \mathrm{~cm}^{-1}, 1,595 \mathrm{~cm}^{-1}\right)$ were noted in IR spectra of EDTA and formaldehyde $+\mathrm{NaOH}$ processes (Fig. 3b), probably being attributable to the complexation of EPS with formaldehyde or EDTA (Comte et al. 2006), or the presence of humic acids extracted with these two schemes (Tan 2003; Gossart et al. 2003; Meissl et al. 2007).

Considering the relatively high extraction effectiveness, low risk to release intercellular materials (low DNA content and similar IR spectra with control), ultrasonication scheme presents a gentle and efficient way of EPS extraction from the present wastewater sludge flocs. This scheme is assumed to disperse the flocs and release flocs entrapped and loosely bound enzymes to the bulk solution (Goel et al. 1998).

Enzymatic distribution in the sludge matrix

Based on data shown in Table 2, most protease activity was bound with pellets, with minor fraction associated with TBEPS and LB-EPS fractions. While $\alpha$-amylase and $\alpha$ glucosidase activities largely appeared in the LB-EPS fraction, with corresponding minor quantities detected with TB-EPS and with pellets. Therefore, we can infer that protease is bound to cell surface, i.e., ecto-enzyme, but $\alpha$ amylase and $\alpha$-glucosidase are immobilized in the EPS matrix in the free form, i.e., exo-enzymes.

Correlation between enzymatic distribution and biochemical composition of sludge

Biochemical composition of sludge is shown in Table 5 . Bivariate correlation analyses were carried out using the software SPSS version 11.0 for Windows (SPSS, Chicago, IL, USA). The ratio of proteins to polysaccharides (2.0-7.5) was within the range which represents most of the activated

Table $4 \alpha$-Glucosidase activities in sludge flocs

\begin{tabular}{|c|c|c|c|c|}
\hline \multirow[t]{2}{*}{ Extraction processes } & \multicolumn{4}{|c|}{$\alpha$-Glucosidase activities ( $\mu \mathrm{mol} \min ^{-1} \mathrm{~g}^{-1}$ VSS) } \\
\hline & LB-EPS & TB-EPS & Pellet & Total \\
\hline Control & & 40.9 & 42.1 & 271 \\
\hline Ultrasonication & & 64.4 & 66.2 & 319 \\
\hline EDTA & & 56.4 & 60.2 & 305 \\
\hline Formaldehyde & 188 & 17.1 & 17.0 & 222 \\
\hline Formaldehyde + ultrasonication & & 0 & 0 & 188 \\
\hline Formaldehyde $+\mathrm{NaOH}$ & & 20.1 & 18.6 & 227 \\
\hline CER & & 0 & 0 & 188 \\
\hline
\end{tabular}




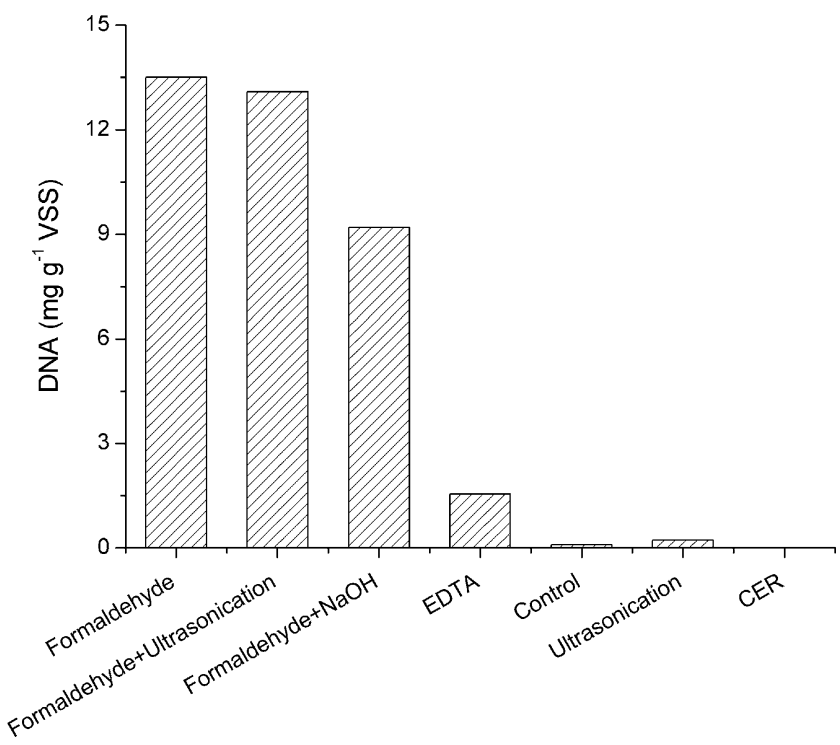

Fig. 2 DNA content in the TB-EPS extracted by seven processes

sludge flocs of WWTP (Liu and Fang 2003). Based on Table 6, the strong correlation is found between proteins and polysaccharides $\left(R^{2}=0.783\right)$, suggesting that their ratio is less affected by the different enzymatic extraction processes but determined by the nature of the sludge. In contrast, no significant correlation could be found between the other biochemical compositions of EPS, i.e., proteins, polysaccharides, and humic acids, and between the biochemical compositions and the distribution of enzymes (protease, $\alpha$-amylase, and $\alpha$-glucosidase). In addition, the partition of enzymatic activities in pellet was highly correlated $\left(R^{2}>0.882\right)$ with the total enzymatic activities, indicating that the enzymatic activities in pellet might be slightly affected by extraction processes. The observations that $\alpha$-amylase activity in pellets markedly correlated with those in total sludge flocs and the $\alpha$-glucosidase distributed in all fractions of sludge flocs suggest that polysaccharideutilizing bacterial population lives in clusters. Meanwhile, the $\alpha$-amylase activity in TB-EPS fraction evidently
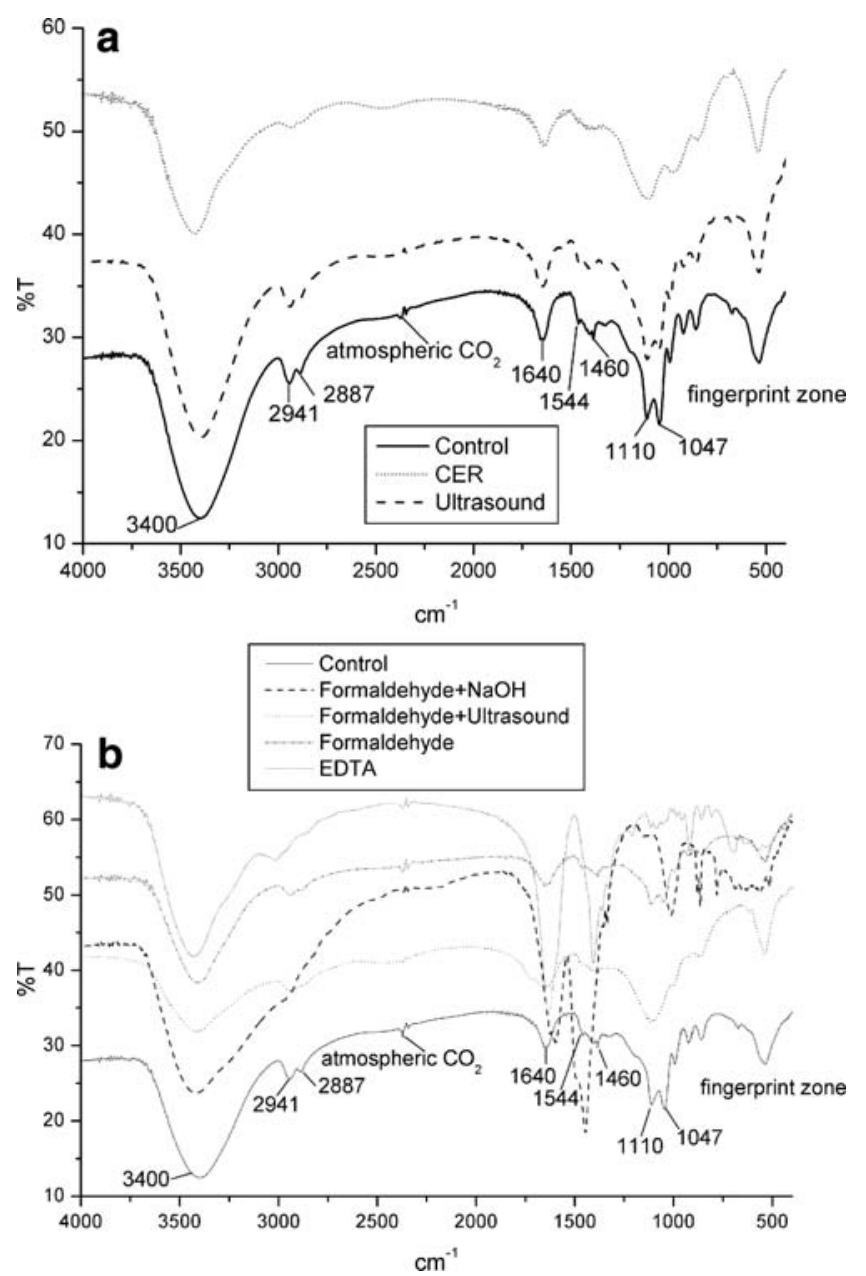

Fig. 3 IR spectra of TB-EPS extracted by different processes: a control and physical processes; $\mathbf{b}$ control and chemical processes

correlated with that of protease in TB-EPS and pellets fractions, indicating that polysaccharide-utilizing bacterial population and protein-utilizing bacterial population might be the mutualistic symbiosis in TB-EPS and pellet regions of flocs.

Table 5 Biochemical composition of EPS ( $\mathrm{mg} \mathrm{g}^{-1}$ VSS)

\begin{tabular}{lllll}
\hline Components & Extraction process & Proteins & Humic acids & Polysaccharides \\
\hline LB-EPS & Centrifugation & 47.0 & 0.11 & 5.30 \\
& Control & 50.2 & 0.11 & 9.41 \\
& Ultrasonication & 42.7 & 0.87 & 16.2 \\
TB-EPS & EDTA & 63.0 & 18.1 & 12.2 \\
& Formaldehyde & 11.3 & 0.72 & 5.65 \\
& Formaldehyde+ultrasonication & 52.7 & 1.62 & 8.43 \\
& Formaldehyde+NaOH & 114 & 13.0 & 29.8 \\
\hline
\end{tabular}


Table 6 Coefficients of correlation $\left(R^{2}\right)$ for linear regression between the various parameters $(n=7)$

\begin{tabular}{|c|c|c|c|c|c|c|c|c|c|c|c|c|}
\hline & $\operatorname{Pr}$ & HA & Po & $\operatorname{Pr}(\mathrm{TB})$ & $\operatorname{Pr}(\mathrm{P})$ & $\operatorname{Pr}(\mathrm{T})$ & $\alpha-a(\mathrm{~TB})$ & $\alpha-a(P)$ & $\alpha-a(T)$ & $\alpha-g(\mathrm{~TB})$ & $\alpha-g(P)$ & $\alpha-g(T)$ \\
\hline $\operatorname{Pr}$ & 1 & 0.452 & $0.783^{\mathrm{a}}$ & 0.243 & 0.426 & 0.456 & $0.615^{\mathrm{b}}$ & 0.000 & 0.083 & 0.003 & 0.008 & 0.004 \\
\hline HA & & 1 & 0.314 & 0.023 & 0.210 & 0.228 & 0.514 & 0.076 & 0.236 & 0.087 & 0.123 & 0.104 \\
\hline Po & & & 1 & 0.046 & 0.209 & 0.205 & 0.516 & 0.035 & 0.171 & 0.055 & 0.075 & 0.064 \\
\hline $\operatorname{Pr}(\mathrm{TB})$ & & & & 1 & 0.237 & 0.335 & 0.284 & 0.045 & 0.135 & 0.003 & 0.005 & 0.003 \\
\hline $\operatorname{Pr}(\mathrm{P})$ & & & & & 1 & $0.986^{\mathrm{a}}$ & $0.661^{\mathrm{b}}$ & 0.055 & 0.010 & 0.083 & 0.062 & 0.073 \\
\hline $\operatorname{Pr}(\mathrm{T})$ & & & & & & 1 & $0.699^{\mathrm{b}}$ & 0.030 & 0.025 & 0.061 & 0.042 & 0.053 \\
\hline$\alpha-a(T B)$ & & & & & & & 1 & 0.103 & 0.393 & 0.068 & 0.098 & 0.080 \\
\hline$\alpha-a(P)$ & & & & & & & & 1 & $0.882^{\mathrm{a}}$ & $0.764^{\mathrm{b}}$ & $0.799^{\mathrm{a}}$ & $0.781^{\mathrm{a}}$ \\
\hline$\alpha-\mathrm{a}(\mathrm{T})$ & & & & & & & & & 1 & $0.663^{\mathrm{b}}$ & $0.721^{\mathrm{b}}$ & $0.689^{\mathrm{b}}$ \\
\hline$\alpha-g(\mathrm{~TB})$ & & & & & & & & & & 1 & $0.994^{\mathrm{a}}$ & $0.998^{\mathrm{a}}$ \\
\hline$\alpha-g(P)$ & & & & & & & & & & & 1 & $0.998^{\mathrm{a}}$ \\
\hline$\alpha-g(T)$ & & & & & & & & & & & & 1 \\
\hline
\end{tabular}

$\operatorname{Pr}$ Protein, $H A$ humic acids, $P$ o polysaccharides, $\operatorname{Pr}(T B)$ protease(TB), $\operatorname{Pr}(P)$ protease $(\mathrm{P}), \operatorname{Pr}(T)$ protease(T), $\alpha$ - $a(T B) \alpha$-amylase(TB), $\alpha$ - $a(P)$ $\alpha$-amylase(P), $\alpha$-a(T) $\alpha$-amylase(T), $\alpha$-g(TB) $\alpha$-glucosidase(TB), $\alpha$-g(P) $\alpha$-glucosidase(P), $\alpha-g(T) \alpha$-glucosidase(T), (TB) TB-EPS, $(P)$ pellet, (T) total

${ }^{\text {a }}$ Correlation is significant at the 0.01 level (two-tailed).

${ }^{\mathrm{b}}$ Correlation is significant at the 0.05 level (two-tailed).

\section{Discussion}

The ultrasonication process showed the higher extraction efficiency for the tested enzymes including protease (23.2 \pm $\left.3.6 \mu \mathrm{mol} \mathrm{m^{-1 }} \mathrm{g}^{-1} \mathrm{VSS}\right), \alpha$-amylase $(8.31 \pm 0.80 \mu \mathrm{mol}$ $\left.\min ^{-1} \mathrm{~g}^{-1} \mathrm{VSS}\right)$, and $\alpha$-glucosidase (131 $\mu \mathrm{mol} \mathrm{min}^{-1} \mathrm{~g}^{-1}$ VSS) and low risk to release intercellular materials (low DNA content and similar IR spectra with control). Therefore, the ultrasonication process is a gentle and efficient enzymatic extraction process for the tested enzymes including protease, $\alpha$-amylase, and $\alpha$-glucosidase.

The low-energy ultrasonication, corresponding with $0.2 \mathrm{~W} \mathrm{~cm}^{-2}$, is verified to enhance enzymatic activities in this experiment. The enhancement of enzymatic activities may be attributed to the fact that ultrasonic extraction can significantly break up sludge matrix and thus release a large amount of enzymes embedded in sludge floc matrix. The result is consistent with the observations of Balasundaram and Harrison (2006) that $88 \%$ of acid phosphatase and $67 \%$ of $\beta$-galactosidase were released at a cavitation number of 0.17 . In addition, some other hypotheses have been proposed to explain how the enzymatic activity is enhanced by the ultrasonication treatment (Schlafer et al. 2000; Capelo et al. 2004; Liu et al. 2003). For example, Liu et al. (2003) indicated that the enhancement of enzyme transport and hydrolysis activities seemed to be an ultrasonication-induced metabolic response of cells by modifying cellular metabolisms or facilitating the uptake of nutrient. Therefore, the mechanism deserves more research because it is far from being fully understood.

The literatures contain contradictory reports on the composition of EPS in bioaggregates, especially the ratio of carbohydrate to protein. Some researchers have reported that EPS were composed mainly of carbohydrates (Morgan et al. 1990; Fang et al. 2002), while others found protein to be the predominant component of EPS (Fukuzaki et al. 1995; Liu and Fang 2003; Raszka et al. 2006). In fact, the ratio of protein and carbohydrate depends on the nature of wastewater, the extraction protocol, analytical tools of chemical compositions, and so on (Frølund et al. 1995). Additionally, Frølund et al. (1995) suggested that the presence of enzyme yielded high protein-to-carbohydrate ratio noted for EPS. However, in the present work, the quantity of enzyme presented negligible fractions of total proteins in sludge flocs.

It is very important to understand the enzymatic distribution in sludge flocs because enzyme activities reflect their microbial activities when degrading organic matters in wastewater (Nybroe et al. 1992). Although the enzymatic activities have been detected previously in activated sludge, it had not been divided EPS into LBEPS and TB-EPS describing enzyme distributions in the sludge flocs before this study. A better understanding of the distribution of enzymes in the different fractions of activated sludge should offer a more thorough understanding of biological processes, and possibly lead to even higher removal efficiencies or better control over the process. Our results suggested that protease activity was mainly localized in the pellet region, only a minor proportion distributed in the TB-EPS region, and scarcely detected in the LB-EPS; while $\alpha$-amylase and $\alpha$-glucosidase activities were largely appeared in the LB-EPS region, and minor amounts of them were detected in the TB-EPS or pellet region. Therefore, we can infer that protease is bound to cell surface, i.e., ectoenzyme, while $\alpha$-amylase and $\alpha$-glucosidase are immobilized in the EPS matrix in the free form, i.e., exo-enzymes. 
In the present work, $44-65 \%$ of $\alpha$-amylase and 59 $100 \%$ of $\alpha$-glucosidase activities were combined with LBEPS, suggesting that the LB-EPS could play an important role on enzymatic hydrolysis of polysaccharides. As we know, substrates in surrounding liquid, when approaching a floc, could easily reach the LB-EPS fraction, and hence, the incorporated enzymes. Meanwhile, the high $\alpha$-amylase, $\alpha$ glucosidase, and no protease activities in LB-EPS indicated that carbohydrates would be hydrolyzed first at the rim regime. The substrates need to pass through certain gel layers to reach the TB-EPS and the pellets. Our results also indicate that most protease was combined with the pellets, suggesting that the protein-utilizing bacterial population was mainly present in the pellet region. Therefore, we can infer that possible incorporation of mass transfer limit of proteins through flocs interior to hydrolysis. The present experimental data correlated with the results of Frølund et al. (1995) that a major part of $\alpha$-glucosidase in the activated sludge was located in the sludge EPS matrix using CER method, and with those of Cadoret et al. (2002) that $23 \%$ of protease, $44 \%$ of $\alpha$-amylase, and $5 \%$ of $\alpha$ glucosidase activities were associated with EPS fraction of the flocs, while the rest of enzymatic activities were bound with the pellets. Just, the present work revealed a detailed description on enzymes in LB-EPS and TB-EPS, which presents a rational description of EPS in sludge flocs. The $\alpha$-amylase and $\alpha$-glucosidase with LB-EPS were easily released to bulk solution in wastewater treatment.

Acknowledgment The authors wish to thank the National Hi-Tech Research and Development Program of China (2006AA06Z384).

\section{References}

APHA, AWWA, WEF (1998) Standard methods for the examination of water and wastewater, 20nd edn. Americal Public Health Association/American Water Works Associaation/Water Environment Federation, Washington, DC, USA

Balasundaram B, Harrison STL (2006) Study of physical and biological factors involved in the disruption of $E$. coli by hydrodynamic cavitation. Biotechnol Prog 22:907-913

Bernfeld O (1955) Amylases, alpha and beta. Academic, New York, USA

Cadoret A, Conrad A, Block JC (2002) Availability of low and high molecular weight substrates to extracellular enzymes in whole and dispersed activated sludges. Enzyme Microb Technol 31:179-186

Capelo JL, Ximenez-Embun P, Madrid-Albarran Y, Camara C (2004) Enzymatic probe sonication: enhancement of protease-catalyzed hydrolysis of selenium bound to proteins in yeast. Anal Chem 76:233-237

Comte S, Guibaud G, Baudu M (2006) Relations between extraction protocols for activated sludge extracellular polymeric substances (EPS) and EPS complexation properties. Part I. Comparison of the efficiency of eight EPS extraction methods. Enzyme Microb Technol 38:237-245

Fang HHP, Liu H, Zhang T (2002) Characterization of a hydrogenproducing granular sludge. Biotechnol Bioeng 78:44-51

Frølund B, Keiding K, Nielsen P (1995) Enzymatic activity in the activated sludge flocs matrix. Appl Microbiol Biotechnol 43:755-761

Frølund B, Palmgren R, Keiding K, Nielsen P (1996) Extraction of extracellular polymers from activated sludge using a cation ion exchange resin. Water Res 30:1749-1758

Fukuzaki S, Nishio N, Nagai S (1995) High rate performance and characterization of granular methanogenic sludges in upflow anaerobic sludge blanket reactors fed with various defined substrates. J Ferment Bioeng 79:354-359

Gaudy AF (1962) Colorimetric determination of protein and carbohydrate. Indust Wat Wastes 7:17-22

Gessesse A, Dueholm T, Petersen SB, Nielsen PH (2003) Lipase and protease extraction from activated sludge. Water Res 37:3652-3657

Goel R, Mino T, Satoh H, Matsup T (1998) Enzyme activities under anaerobic and aerobic conditions in activated sludge sequencing batch reactor. Water Res 32:2081-2088

Gossart P, Semmoud A, Ruckebusch C, Huvenne JP (2003) Multivariate curve resolution applied to Fourier transform infrared spectra of macromolecules: structural characterisation of the acid form and the salt form of humic acids in interaction with lead. Anal Chim Acta 477:201-209

Kim IS, Jang N (2006) The effect of calcium on the membrane biofouling in the membrane bioreactor (MBR). Water Res 40:2756-2764

Li XY, Yang SF (2007) Influence of loosely bound extracellular polymeric substances (EPS) on the flocculation, sedimentation and dewaterability of activated sludge. Water Res 41:1022-1030

Liu H, Fang HHP (2002) Extraction of extracellular polymeric substances (EPS) of sludges. J Biotechnol 95:249-256

Liu Y, Fang HHP (2003) Influences of extracellular polymeric substances (EPS) on flocculation, settling, and dewatering of activated sludge. Crit Rev Environ Sci Technol 33:237-273

Liu Y, Takatsuki H, Yoshikoshi A, Wang B, Sakanishi A (2003) Effects of ultrasound on the growth and vacuolar $\mathrm{H}^{+}$-ATPase activity of aloe arborescens callus cells. Colloids Surf B Biointerfaces 32:105-116

Lowry OH, Rosebrough NJ, Farn A, Randall R (1951) Protein measurement with the folin phenol reagent. J Biol Chem 193:265-275

Meissl K, Smidt E, Schwanninger M (2007) Prediction of humic acid content and respiration activity of biogenic waste by means of Fourier transform infrared (FTIR) spectra and partial least squares regression (PLS-R) models. Talanta 72:791-799

Ministry of light industry of China (1993) General methods of determination for industrial enzymes (QB/T 1803-1993). China Light Industry Press, Beijing, China

Morgan JN, Forster CF, Evison L (1990) A comparative study of the nature of biopolymers extracted from anaerobic and activated sludges. Water Res 24:743-750

Molina-Munoz M, Poyatos JM, Vilchez R, Hontoria E, Rodelas B, Gonzalez-Lopez J (2007) Effect of the concentration of suspended solids on the enzymatic activities and biodiversity of a submerged membrane bioreactor for aerobic treatment of domestic wastewater. Appl Microbiol Biotechnol 73:1441-1451

Nielsen PH, Jahn A (1999) Extraction of EPS. In: Wingender J, Neu $\mathrm{TR}$, Flemming HC (eds) Microbial extracellular polymeric substances. Spinger, Berlin, pp 49-72

Nybroe O, Jorgensen PE, Henze M (1992) Enzyme activities in waste water and activated sludge. Water Res 26:579-584

Poxon TL, Darby JL (1997) Extracellular polyanions in digested sludge: measurement and relationship to sludge dewaterability. Water Res 31:749-758 
Ramesh A, Lee DJ, Hong SG (2006) Soluble microbial products (SMP) and extracellular polymeric substances (EPS) from wastewater sludge. Appl Microbiol Biotechnol 73:219-225

Ramesh A, Lee DJ, Lai JY (2007) Membrane biofouling by extracellular polymeric substances or soluble microbial products from membrane bioreactor sludge. Appl Microbiol Biotechnol 74:699-707

Raszka A, Chorvatova M, Wanner J (2006) The role and significance of extracellular polymers in activated sludge Part I: literature review. Acta Hydrochim Hydrobiol 34:411-424

Schlafer O, Sievers M, Klotzbucher H, Onyeche TI (2000) Improvement of biological activity by low energy ultrasound assisted bireactors. Ultrasonics 38:711-716
Sheng GP, Yu HQ (2006) Characterization of extracellular polymeric substances of aerobic and anaerobic sludge using three-demensional excitation and emission matrix fluorescence spectroscopy. Water Res 40:1233-1239

Sun Y, Clinkenbeard KD, Clarke C, Cudd L, Highlander SK, Dabo SM (1999) Pasteurella haemolytica leukotoxin induced apoptosis of bovine lymphocytes involves DNA fragmentation. Vet. Microbiol 65:153-166

Tan KH (2003) Humic matter in soil and the environment — principles and controversies. Marcel Dekker, New York

Zhang XG, Bishop PL, Kinkle BK (1999) Comparison of extraction methods for quantifying extracellular polymers in biofilms. Water Sci Technol 39:211-218 